\title{
TEMPORAL VARIATIONS IN GEOPHYSICAL FIELDS AND EARTHQUAKE FORECASTING ISSUES
}

\author{
V. A. Parovyshny, V. N. Senachin, 0. V. Veselov, E. V. Kochergin \\ Institute of Marine Geology and Geophysics, Far East Branch of RAS, Yuzhno-Sakhalinsk, Russia
}

\begin{abstract}
Results of the experimental long-term monitoring programme are presented. It is aimed at studying natural geophysical fields located above the gas deposit in the zone impacted by the active regional fault, and its objectives are to reveal how such fields are changing with time and to establish a relationship between the temporal changes and seismicity. According to the database it determines several typical indicators of variations in the geophysical fields, which take place only above the gas deposit. It is concluded that periods, when natural geophysical fields located above the gas deposit are unstable, are preceding the final phase of preparation of seismic events.
\end{abstract}

Key words: gravimetry, thermometry, magnetic measurements, natural electric field, earthquake precursors, geodynamics, gas deposit, prospecting indicators of oil and gas fields, Sakhalin.

Recommended by V.S. Imaev

For citation: Parovyshny V.A., Senachin V.N., Veselov O.V., Kochergin E.V. 2015. Temporal variations in geophysical fields and earthquake forecasting issues. Geodynamics \& Tectonophysics 6 (1), $63-76$. doi:10.5800/GT-2015-6-1-0172.

\section{ВРЕМЕННЫЕ ИЗМЕНЕНИЯ ЕСТЕСТВЕННЫХ ГЕОФИЗИЧЕСКИХ ПОЛЕЙ В СВЯЗИ С ПРОБЛЕМОЙ ПРОГНОЗА СЕЙСМИЧЕСКИХ СОБЫТИЙ}

\author{
В. А. Паровышный, В. Н. Сеначин, О. В. Веселов, Е. В. Кочергин \\ Институт морской геологии и геофизики ДВО РАН, Южно-Сахалинск, Россия
}

\begin{abstract}
Аннотация: Рассматриваются результаты экспериментальных исследований, направленных на изучение характера временных изменений естественных геофизических полей (ЕГП) над залежью газа, расположенной в зоне влияния активного регионального разлома, а также выявление связи этих изменений с сейсмичностью. Определен ряд характерных признаков изменения полей, проявляющихся только над залежью газа. Установлено, что проявляющиеся периоды нестабильности ЕГП над залежью газа предшествуют конечной фазе подготовки сейсмических событий.
\end{abstract}

Ключевые слова: гравиметрия, термометрия, магнитометрия, естественное электрическое поле, предвестники землетрясений, геодинамика, газовая залежь, поисковые признаки нефтегазовых месторождений, Сахалин. 


\section{INTRODUCTION}

In 2003, the Geodynamics Laboratory of the Institute of Marine Geology and Geophysics, Far East Branch of RAS commenced implementation of the longterm programme aimed at studying natural geophysical fields located above fluid-saturated geodynamic systems in zones impacted by active regional tectonic faults.

Main research objectives:

(1) Identify typical indicators suggesting the presence of a hydrocarbon deposit with reference to temporal variations in geophysical fields, and, based on such indicators, propose a technique for forecasting oiland-gas bearing capacities of complexly structured facilities located in zones of active faults;

(2) Reveal a relationship between variations of geophysical fields above gas-saturated facilities and seismic events, and assess a possibility for proposing a technology to ensure short-term forecasting of earthquakes.

Prerequisites of this programme were provided by results obtained in studies conducted by the Institute of Physics of the Earth [Bulanzhe, 1986], Institute of Geology and Development of Fossil Fuels [Volgina, 1988, 1990] and geophysicists from Ukrain [Osadchy et al., 1976; Chekalyuk et al., 1974], which revealed specific features of gravity and thermal fields above hydrocarbon accumulations.

\section{GEOLOGICAL SETTINGS OF THE STUDY AREA}

A geophysical survey polygon was equipped in the Yuzhno-Lugovskoe gas field located $4 \mathrm{~km}$ to the west of the Aniva city in South Sakhalin (Fig. 1, A). The polygon's area covers the impact zone of the regional tectonically active Central Sakhalin fault.

The Yuzhno-Lugovskoe field is confined to the lower sub-suite of the Maruyamskaya suite of the Miocene age $\left(\mathrm{N}_{1-2} \mathrm{mr}_{1}\right)$, which consists of 14 sandstone horizons with good and satisfactory reservoir properties. Horizons III to XIII contain methane, and horizons VII to XIII contain gas in commercial quantities. Horizon XIV is the lowest and overall water-bearing. The total thickness of the gas reservoirs is variable in different blocks of the field and ranges from 40 to $80 \mathrm{~m}$.

In the southern block of the field, the lower gaswater contact is located at a depth of $1368 \mathrm{~m}$. The gas deposit was discovered in 1971 when Well 1 penetrated a gas reservoir (Fig. $1, B$ ). The deposit is classified as a small one as its total gas reserves do not exceed 2 billion $\mathrm{m}^{3}$.

According to the available structural geological data on the region, the gas deposit is located in the gentle sloping fold which amplitude amounts to a few tens of meters and her dimension decreases upward the section (Fig. 2).

In all the blocks, except the northern periclinal one, the gas-water contact conforms to contours of deposits located in horizon XIII. In the northern block, horizon XIII contains water reservoirs, and horizons XI and XII contain reservoirs with gas in non-commercial quantities. Faults bordering the productive lower horizons (IX-XIII) do not go up to the ground surface. In plan, contours of reservoirs in productive horizons, that are hypsometrically located above horizon XIII, do not go beyond the contour of the reservoir in horizon XIII. Structural plans of other horizons are significantly different from the above-mentioned one. However, due to the fact that they contain the main gas reserves, we arbitrarily assume that the main component of quantifiable changes in geophysical fields results from changes in the reservoir confined to horizon XIII.

\section{METHODS OF FIELD RESEARCH}

The field is operated only during the winter season from mid-November to mid-May, and it may be thus believed that the gas deposit is not subject to any anthropogenic impact during monitoring cycles (from July through October).

For achieving the first objective, geophysical surveys were conducted at the polygon along three profiles across all the blocks (see Fig. 1, $B$ ).

The following survey techniques were applied:

(1) High-precision gravity surveys by profiles with account of an observed gravity value error, $\Delta \mathrm{g}_{\mathrm{H}}$. Three first-class gravimeters were used simultaneously in the two-stage system (reference network - routine network) in the conventional level from the same reference point located $650 \mathrm{~m}$ to the west of the deposit's contour. The total root-mean-square error of $\Delta \mathrm{g}_{\mathrm{н}}$ determinations by cycles ranged from \pm 0.016 to $\pm 0.019 \mathrm{mGal}$;

(2) Temperature logging at shallow depths $(1.5 \mathrm{~m})$ with account of a temperature measurement error of $\pm 0.05^{\circ} \mathrm{C}$;

(3) Geomagnetic surveys conducted simultaneously with recording of geomagnetic field variations, with account of a determination error, $\Delta \mathrm{Ta} \pm 1 \mathrm{nT}$.

The surveys were carried out in a cyclical pattern, two monitoring cycles each summer and autumn with a one-month interval between the cycles during the season. Properly equipped stations recorded all the observation in each cycle almost simultaneously for 12-14 hours. Our survey technique is described in a more detail in [Parovyshny et al., 2008, 2009].

Based on results of six monitoring cycles conducted in 2003, 2004 and 2006, the following main indicators of productivity were established: 

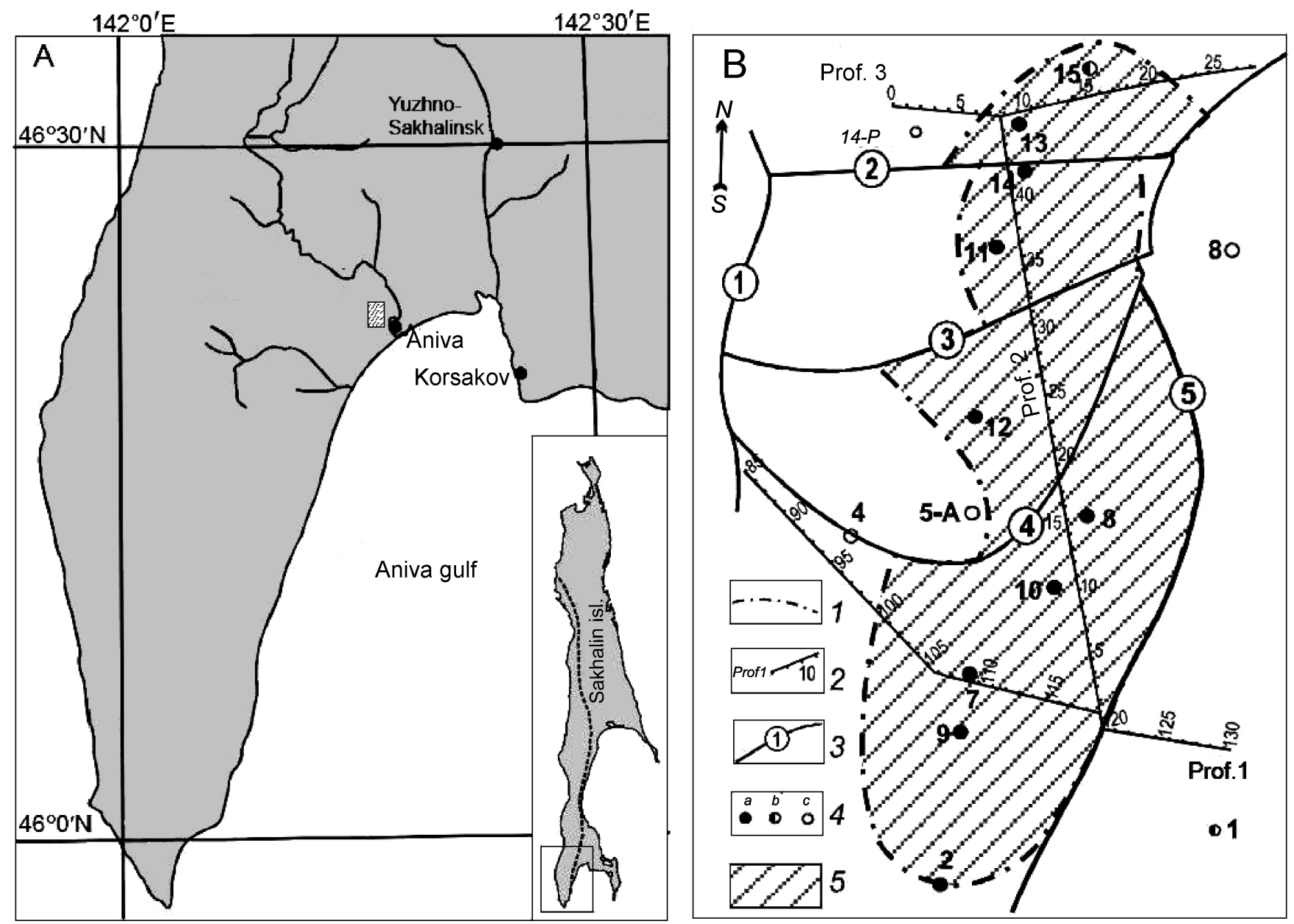

Fig. 1. Geographic location $(A)$ and structural scheme $(B)$ of the geodynamic survey polygon.

1 - contour of the gas deposit; 2 - profiles of complex geophysical surveys; 3 - main faults revealed by seismic survey and drilling data; 4 wells with industrial inflow (a), with non-industrial inflow (b), without inflow (c); 5 - area of the gas deposit. Spacing of survey marks on profiles: 50 m. In the inset in Fig. 1, $A$, the dotted line shows the location of the Central Sakhalin fault.

Рис. 1. Географическое положение $(A)$ и структурная схема полигона $(B)$.

1 - контур газовой залежи; 2 - профили комплексных геофизических наблюдений; 3 - основные разрывные нарушения по данным сейсморазведки и бурения; 4 - скважины: а - с промышленными притоками, b - с непромышленными притоками, с - непродуктивные; 5 - площадь залежи. Расстояние между пикетами на профилях - 50 м. На врезке рис. $1, A$, показано положение Центрально-Сахалинского разлома.

(1) Within the pool outline, the gravity field is unstable in time. Values of $\Delta \mathrm{g}_{\mathrm{н}}$ differ by $\pm 0.16 \mathrm{mGal}$ between the survey cycles;

(2) Productive blocks are characterized by the gravity field instability maximum values correlating with the relative maximum temperature;

(3) Characteristics of the gravity field and the thermal field above the gas deposit are synchronously changeable. Within the gas deposit's area, higher voltage values of the gravity field correspond to higher temperatures, and vice versa - lower voltage values of the gravity field are associated with lower temperatures in the thermal field (Fig. 3);

(4) During the natural seismic impulse travel time, the temperature is increased within the gas deposit's area (Fig. 4).

The above-mentioned indicators can provide a basis for proposing a method for identification of hydrocarbon deposits on surveyed sites before commencement of deep drilling on such sites.

\section{RESULTS AND DISCUSSION}

To consider relationships between temporal variations in the natural geophysical fields and seismicity, we start with a seismic event of 13 September 2004 $\left(14^{\mathrm{h}} 02^{\mathrm{m}}\right.$ local time $)$. In the gravity survey, it was 


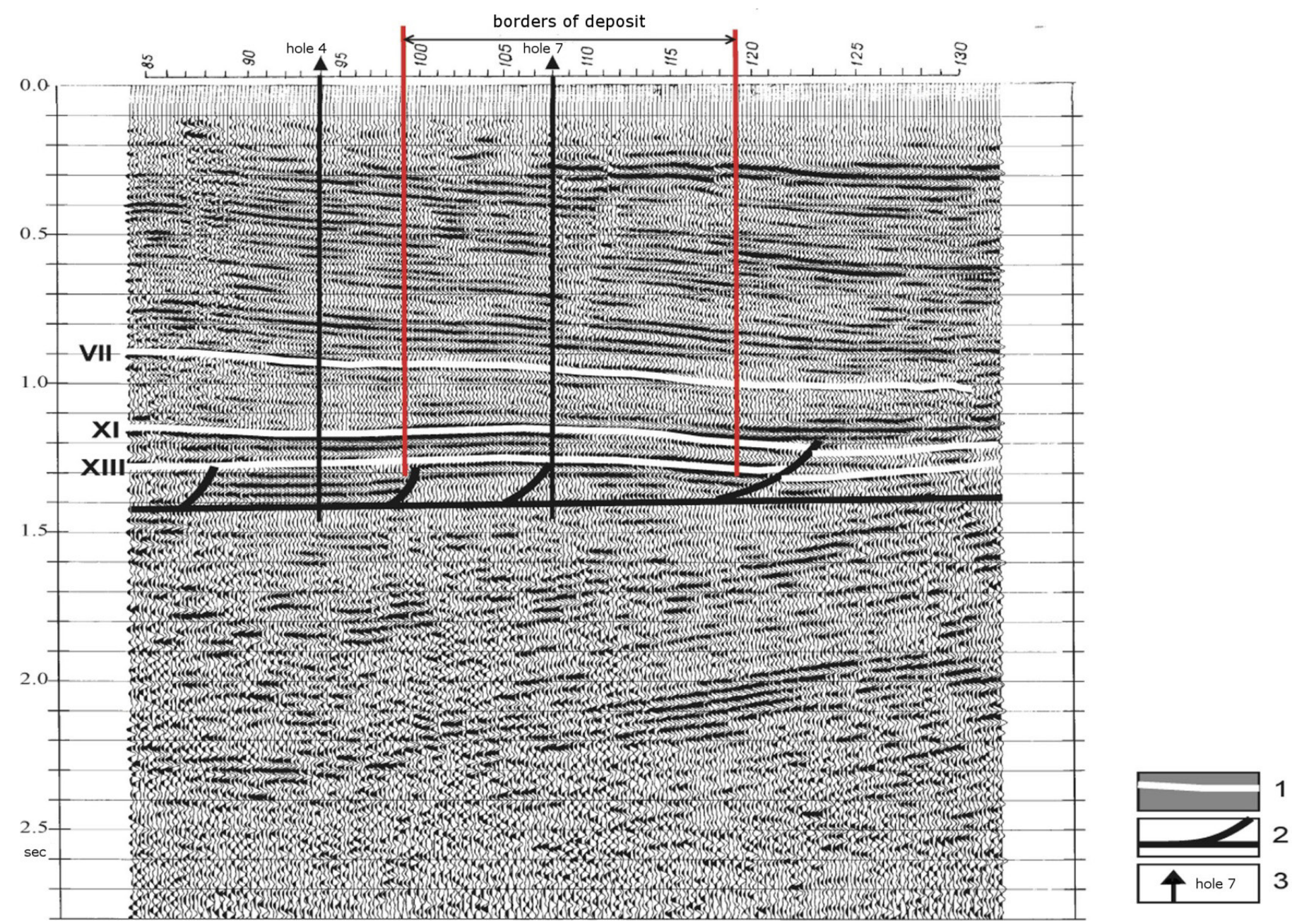

Fig. 2. Time cross-section along profile 9202056 (combined with profile 1 of the geophysical survey polygon) as interpreted by the authors.

1 - productive horizons that are identifiable only in this cross-section; 2 - faults; 3 - wells (productive well \#7, and non-productive well \#4). Spacing of survey marks: $50 \mathrm{~m}$.

Рис. 2. Временной сейсмический разрез по профилю 9202056 в интерпретации авторов (совмещен с профилем 1 геофизического полигона).

1 - номенклатурные продуктивные горизонты (показаны только опознаваемые в данном сечении); 2 - разрывные нарушения; 3 - скважины: № 7 - продуктивная, № 4 - непродуктивная. Расстояние между пикетами 50 м.

marked on profile 1 at the above-mentioned time. Gravimeters recorded sharp non-periodic oscillations of gravity which lasted for over four hours and then became indistinguishable from oscillations caused by the start of a storm. This event was recorded at the abovementioned time by two autonomous seismic stations in Ozhidaevo and Yuzhno-Sakhalinsk, which are located $40 \mathrm{~km}$ north-west and $40 \mathrm{~km}$ north-east of the polygon, respectively. Its parameters were recorded in Bulletin No. 26 covering a period from 11 to 20 September 2004. Temperature logging was conducted on profile 1 from $14^{\mathrm{h}} 31^{\mathrm{m}}$ to $18^{\mathrm{h}} 26^{\mathrm{m}}$ local time on 12 September 2004 , i.e. less than 24 hours before the event, and repeated from $09^{\mathrm{h}} 37^{\mathrm{m}}$ to $12^{\mathrm{h}} 40^{\mathrm{m}}$ on 15 September 2004 .
Comparing the two sets of survey results gives evidence of the temperature increase by $0.5-0.8{ }^{\circ} \mathrm{C}$ within the deposit's area (survey marks 100-119, Fig. 4). This fact contradicts with the regular seasonal temperature decrease that was revealed earlier for this region. At the same time, a regular temperature decrease by $0.10-0.15^{\circ} \mathrm{C}$ was recorded at the profile's segment corresponding to the area above blocks known as nonproductive. At the eastern flank of profile 1 (between survey marks 128 and 132), the same monitoring cycles revealed another positive temperature anomaly that seems to coincide with the western part of the local gas deposit discovered in 1971 when prospecting well No. 1 was drilled in the Zolotorybnaya area. The 


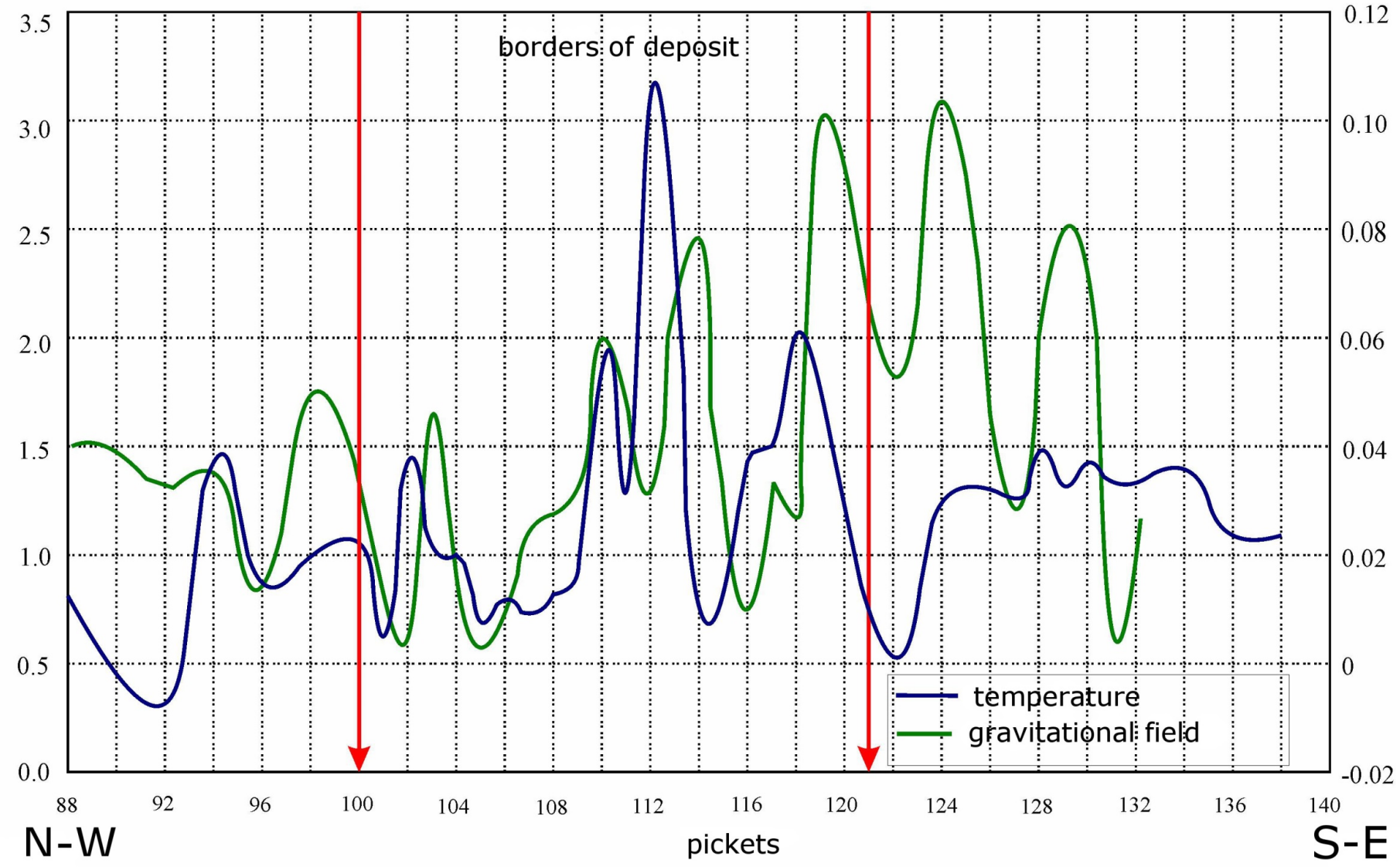

Fig. 3. Variations in the gravity field and the thermal field above the Yuzhno-Lugovsky geophysical survey polygon, profile 1.

Differences ${ }_{\triangle} \mathrm{g}_{\mathrm{н}}$ and ${ }_{\Delta}{ }^{\circ} \mathrm{C}$ between monitoring cycles 3 and 2 conducted on 17 September 2006 and 21 August 2006, respectively. Vertical red arrows mark boundaries of the gas deposit. See the profile's location in Fig. 1, $B$.

Рис. 3. Пример изменения гравитационного и термального полей над залежью Южно-Луговской полигон, профиль 1.

Разности ${ }_{\Delta} \mathrm{g}_{\mathrm{H}}$ и ${ }_{\Delta} \mathrm{t}{ }^{\circ} \mathrm{C}$ между третьим и вторым циклами наблюдений: 17.09.2006 и 21.08. 2006 г. Вертикальными красными стрелками показаны границы залежи. Положение профиля показано на рис. $1, B$.

well is located $300 \mathrm{~m}$ south of the profile's anomalous segment (see Fig. 2). As evidenced by the gravity field monitoring data, the temperature anomaly at this location is accompanied by heightened differences between values of gravity field in the fifth and fourth monitoring cycles. Further surveys can help to expose the eastern termination of the temperature anomaly.

With account of the fact that the rapid temperature inversion occurs above the deposit, it should be kept in mind that its start does not necessarily coincide with the time when a seismic impulse occurs. D.G. Osika [1981] reviewed numerous cases of higher fluid production rates and higher temperatures recorded in seismically active areas a few days before the earthquakes. In the above-described case, it is not excluded that the change in the thermal field above the deposit (temperature increase by $0.7 \div 0.8{ }^{\circ} \mathrm{C}$ within less than two days) is only an episode of the general temperature increase due to the active stage of preparation of a seismic event.

Based on this fact, it was concluded that natural seismic impulses may be the most probable factor causing changes in parameters of the geophysical fields above the deposit. It was thus established that the gas deposit become detectable during a seismic event, and at the same time, it can be viewed as an indicator of changing parameters of the geophysical fields which characterize the geodynamic state of the deposit during the seismic event.

In our subsequent studies, it was revealed that variations in the geodynamic state of the deposit occurred a few hours before a seismic event and were evidenced by perturbations of the geophysical field above the methane deposit which were sharply different from the 


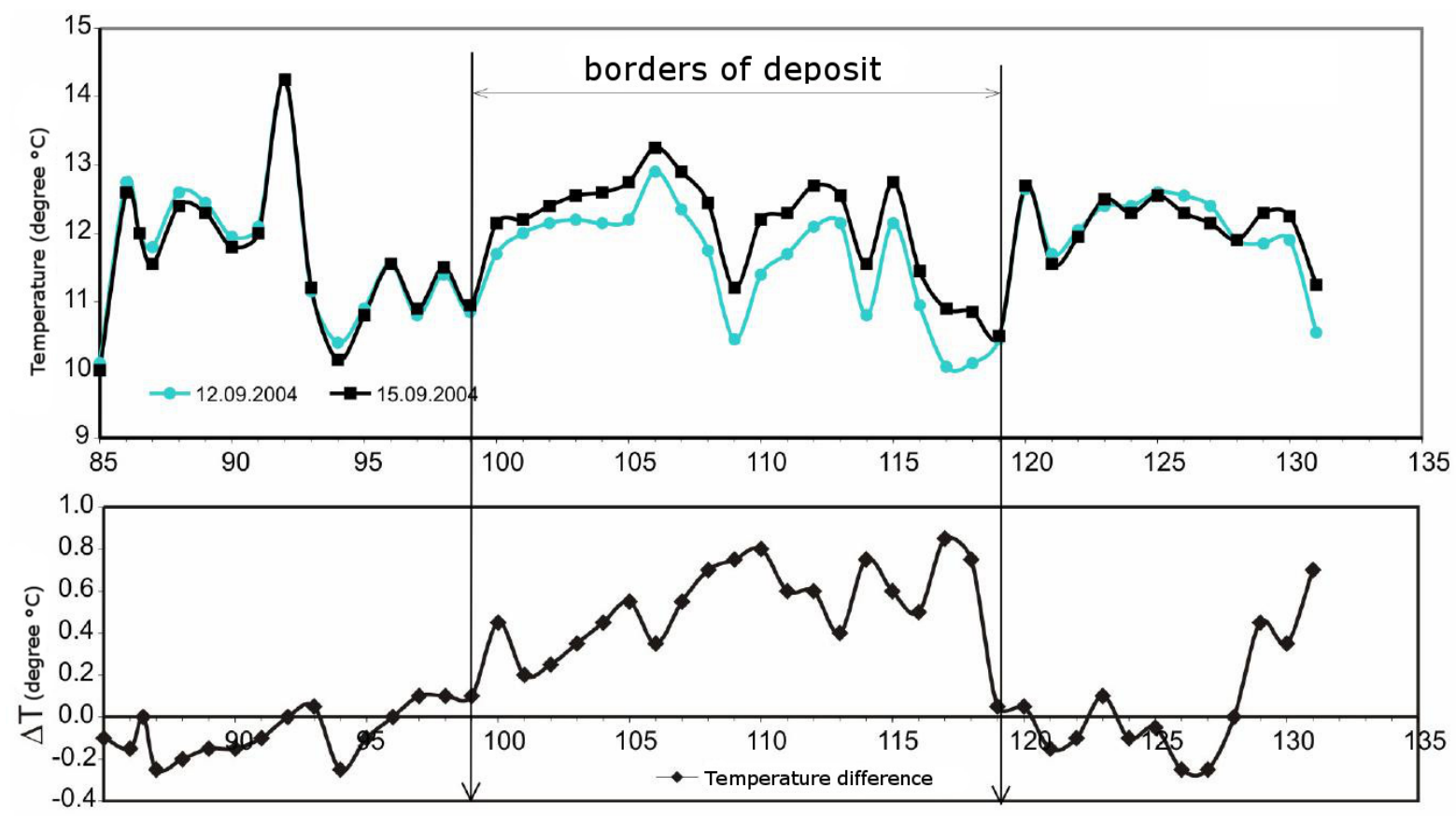

Fig. 4. Temperature variations before and after 13 September 2004 earthquake.

Рис. 4. Графики изменения температур до и после землетрясения 13.09.2004 г.

background voltage values recorded through the seismically placid period (Fig. 5).

It should be noted that Figure 5 illustrates only an episode of the natural electric field in a long period of seismic quiescence. For example, a similar state of the electric field was recorded from late June to midSeptember 2008. In the same period, records by the Sakhalin Seismological Survey did not show any seismic event in the area within a radius of $650 \mathrm{~km}$ from the Yuzhno-Lugovskoy geophysical survey polygon. It can thus be suggested that the electric field perturbations recorded at the polygon were associated with seismic events which epicentres were located only within the Okhotomorskaya plate.

In 2004, the monitoring station was equipped with sensors for non-stop recording of magnetic variations (for establishing relationships between changes in the geophysical fields and seismic events), and a special equipment set was added for measuring variations of the natural electric field. In 2006, a set with four randomly oriented electric dipoles was added (true azimuths of dipole orientations on loop: $0^{\circ}, 40^{\circ}, 90^{\circ}$ and $135^{\circ}$ ) for recording differences of potentials of the natural electric field. The above-described monitoring station operated on the long-term site in the central block of the Yuzhno-Lugovskoe deposit near Well No. 12 (see Fig. 1, B) during summer and autumn in 2006 and 2008. It recorded perturbations of the natural electric field prior to the earthquake $(M=3)$ which epicentre was located $60 \mathrm{~km}$ north of the monitoring site [Parovyshny et al., 2008]. According to the records, the most intense signal was received from the dipole oriented at the azimuth with a difference of $7^{\circ}$ from the direction to the epicentre. With account of this fact, the station was further upgraded for recording variations in the natural electric field in order to obtain directions to the epicentre of the coming earthquake.

From 2010 to 2012, we continue studies of temporal variations in the geophysical fields above the methane deposit on the basis of data obtained on the long-term monitoring site. The main objective was focused on obtaining data that can help determine the time of a coming seismic event and directions to its epicentre. A combination of geophysical methods was used, including recording of the natural electric field and surveys of magnetic and temperature fields.

Electrical logging of the natural electric field was conducted by Polygon-E, an automatic digital computerized station designed and manufactured according to our specification by the Laboratory of Natural Geophysical Fields (S.A. Kazantsev, PhD in Technical Sciences, Technical Team Leader), Institute of Petroleum Geology and Geophysics SB RAS in Novosibirsk, Russia. Records were taken every 10 seconds from the dipoles oriented according to true azimuths and spaced by $30^{\circ}$ on loop, starting from zero. The dipoles were from 120 to $160 \mathrm{~m}$ long. Nonpolarizable electrodes were put in $1.5 \mathrm{~m}$ deep shot-holes in order to eliminate the impacts of electrochemical processes taking place on the ground surface. All the electrodes were placed 


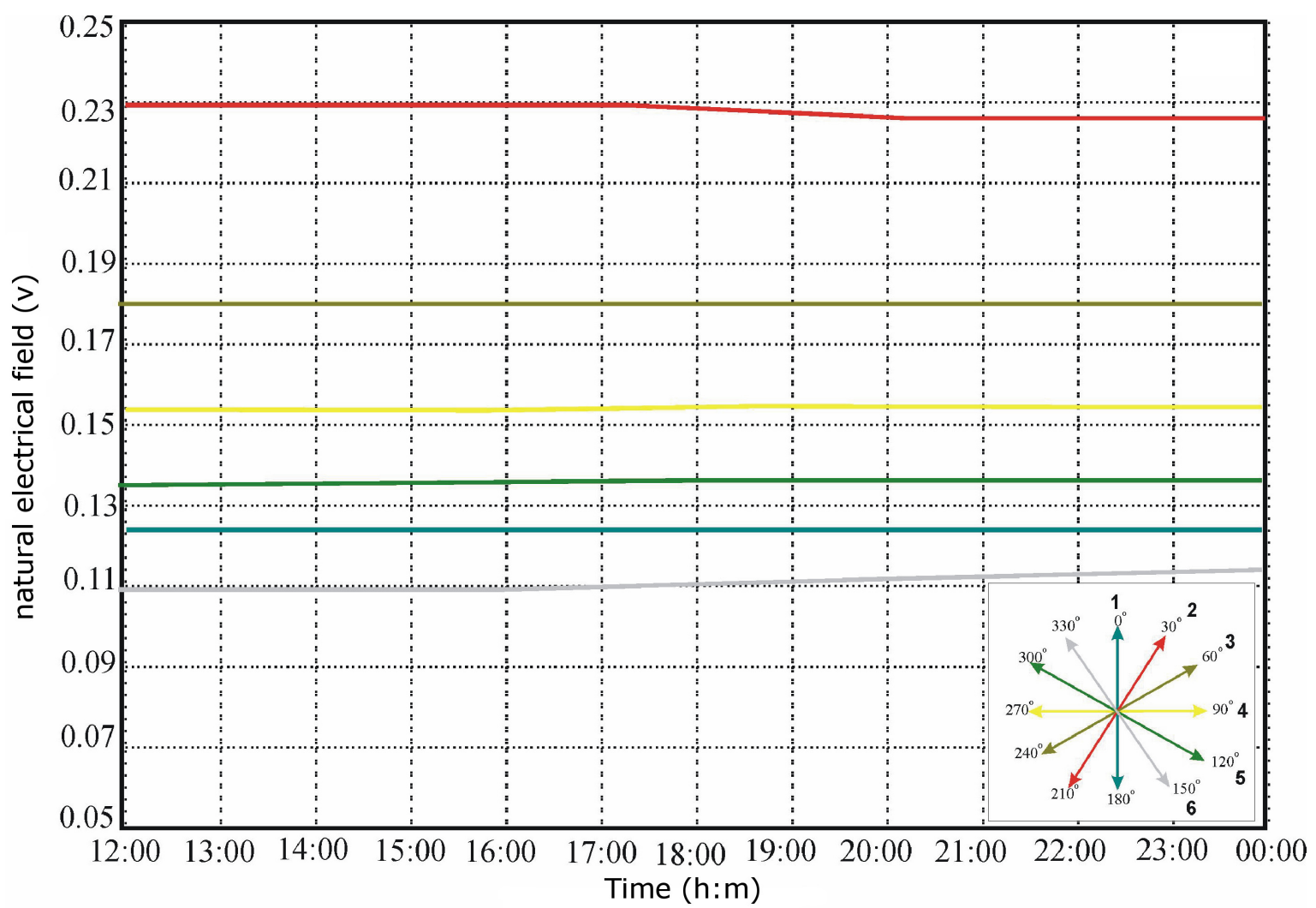

Fig. 5. The natural electric field (NEF) during the seismically placid period as per records on 01 October 2011 . The inset shows orientation of dipoles according to true azimuths and numbers of channels.

Рис. 5. Состояние естественного электрического поля (ЭП) в период отсутствия сейсмических событий 1.10 .2011 г. Здесь и далее: на цветной врезке показаны ориентировка диполей по истинным азимутам и номера каналов записи ЕП.

in approximately equal water-cut and light intensity conditions. In each channel, differences between potentials were determined with an accuracy of \pm 0.5 microvolts.

In 2011, magnetometric surveys were conducted with the use of FM-03 computerized ferroprobe magnetometer manufactured by a subsidiary of the Institute of Terrestrial Magnetism, Ionosphere and Radio Wave Propagation in Moscow, Russia. Readings were automatically recorded at fixed intervals of ten (10) seconds and one (1) minute. The records were included in the computer database, reviewed and archived, as required. The determination accuracy was $\Delta \mathrm{T} \pm 1 \mathrm{nT}$. Drifting of the zero point of FM-03 magnetometer was taken into account; for this purpose, absolute values of $\Delta \mathrm{T}$ were regularly recorded by MMP-203 proton magnetometer.

Since 2012, stationary magnetometric surveys have been conducted with the use of an upgraded MMP-203 proton magnetometer, including a computer-networked electronic unit that ensures direct data recording, reviewing and archiving. The determination accuracy is $\Delta \mathrm{T} \pm 1 \mathrm{nT}$.
Temperature logging was conducted with the use of «Polygon-T» six-channel automatic computerized digital thermometric station that was also manufactured by the Laboratory of Natural Geophysical Fields in Novosibirsk, Russia. Temperature was measured by sensors placed in 3.2 and $2.2 \mathrm{~m}$ deep wells that are located near the monitoring site. In each channel, the temperature determination accuracy was $\pm 0.01{ }^{\circ} \mathrm{C}$. Simultaneous records were taken of air temperature, atmospheric pressure and the above-mentioned parameters.

All the readings were computer recorded, reviewed in a graphical form and archived on site, then processed and compared with the official data from the Seismological Survey.

Our analysis of the long-term monitoring data revealed the following:

(1) In the absence of seismic events, i.e. in conditions of seismic placidity, the geophysical fields are in the placed state with no visible deviations from the background values (Fig. 5);

(2) Perturbations of the geophysical fields above the methane deposit are recorded three to four hours 


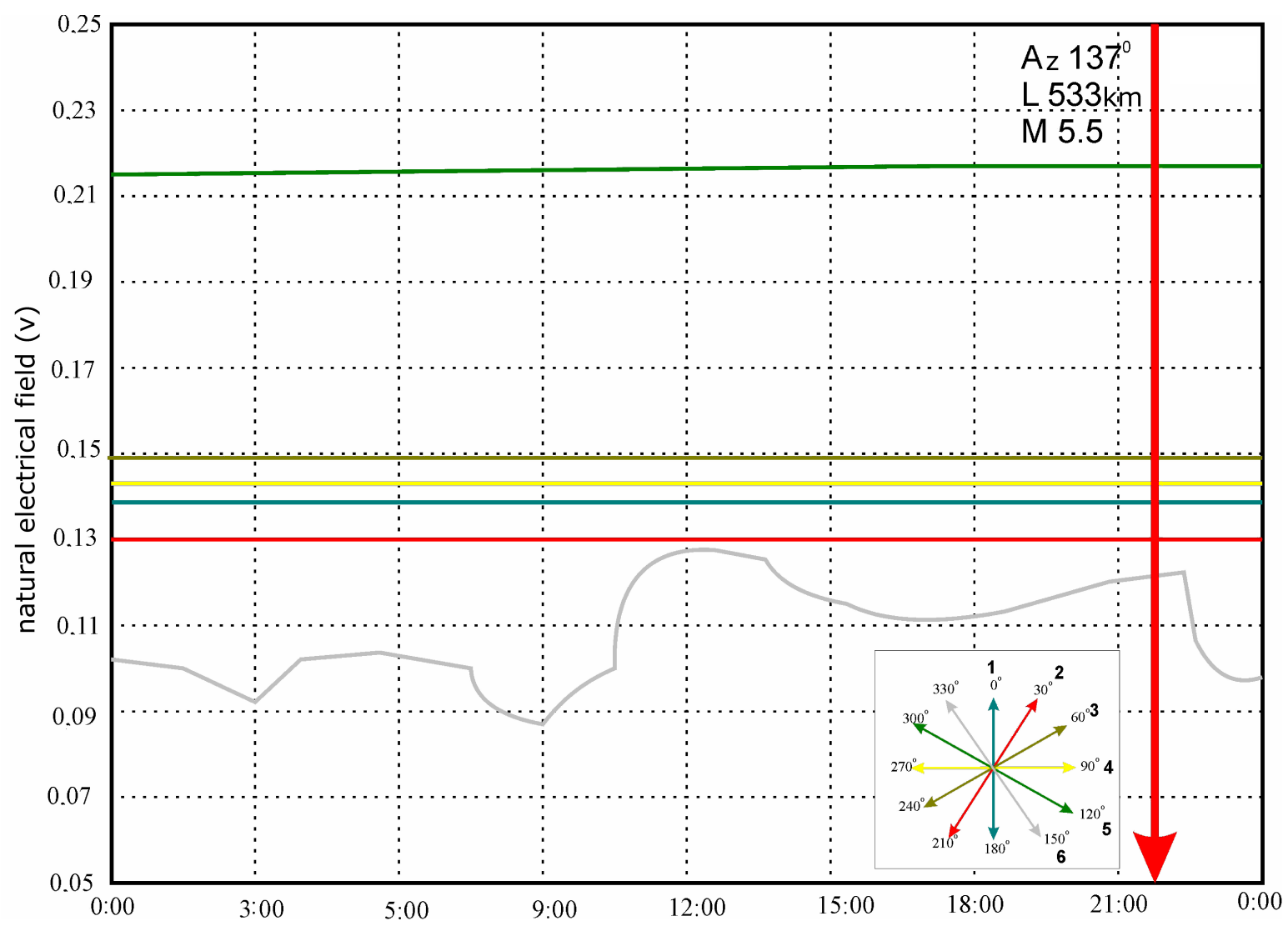

Fig. 6. Variations in the natural electric field as per records in channel 6 (the dipole was oriented at azimuth $150^{\circ}$ ) before 09 November 2011 earthquake that occurred at $21^{\mathrm{h}} 40^{\mathrm{m}}$ local time; its epicentre was located $533 \mathrm{~km}$ away from the monitoring site.

The earthquake timeline is shown by the vertical red line. Earthquake parameters: Az - azimuth (direction) to the earthquake epicentre; $\mathrm{L}$ - distance from the monitoring site to the epicentre; $\mathrm{M}$ - earthquake magnitude.

Рис. 6. Пример изменения естественного электрического поля на канале 6 (ориентировка диполя по аз. $150^{\circ}$ ) 9.11.2011 г. перед землетрясением в 21 ч 40 мин при удалении эпицентра от места наблюдений на 533 км.

Здесь и далее: время реализации сейсмического события показано вертикальной красной линией; обозначение параметров землетрясений: «Az» - азимут (направление) на очаг землетрясения; «L» - расстояние от пункта наблюдений до эпицентра; «M» магнитуда землетрясения.

before seismic events which epicentres are at a distance of $450 \mathrm{~km}$ or more away from the monitoring site (Fig. 6 and 7), and about 20-25 hours before seismic events which epicentres are $100 \mathrm{~km}$ or less away from the monitoring site (see Fig. 7). Timing can be determined unreliably for an earthquake if its epicentre is located more than $650 \mathrm{~km}$ away from the monitoring site;

(3) During the final stage of preparation of a seismic event, the natural electric field is most considerably disturbed, and its perturbations are recorded in channels oriented in the direction azimuthally close to the direction to the epicentre (Fig. 6, 8, and 9).

No obvious relationship has been revealed between air temperature an atmospheric pressure variations and geophysical parameters determined from records taken by the grounded sensors.
The curves shown in Figures 6 and 8 need to be commented as visible disturbances were absent in all the channels, except those oriented towards the epicentre. Moreover, for the majority of seismic events recorded before and after the above-mentioned episodes, the readings were shaped as shown in Figure 9, which means that the perturbations of the electric field before the seismic event were recorded in all the channels, but the highest amplitudes were recorded in the channels oriented towards the earthquake epicentre.

The input data for plotting (see Fig. 6 and 8) and monitoring conditions during recording were thoroughly checked, and we can state that the recording process was not impacted by any hard and/or software failures and/or man-made noise. There were slight deviations ( 15 to $20 \mathrm{mkV}$ ) from the background values in 


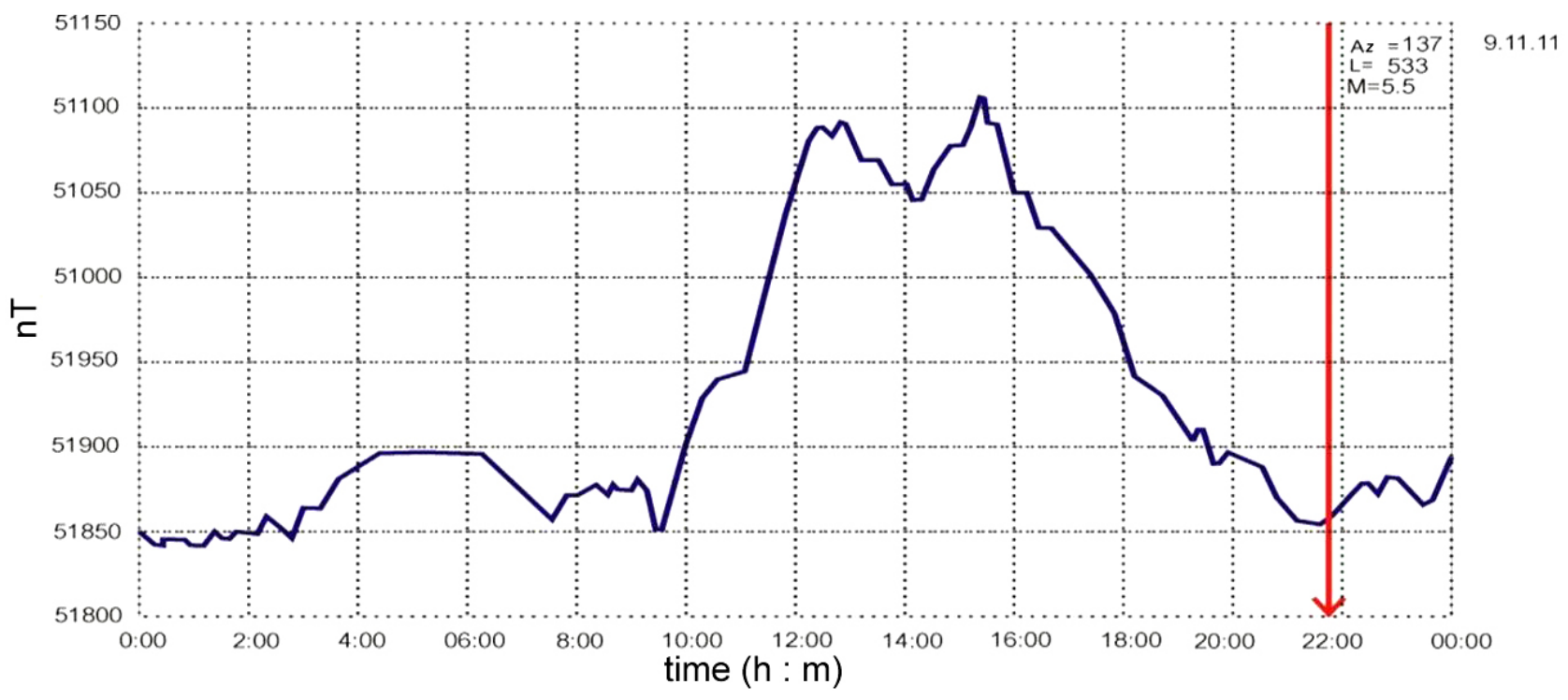

Fig. 7. Variations in the geomagnetic field $(\Delta \mathrm{T})$ on 09 November 2011 before the earthquake that occurred at $21^{\mathrm{h}} 40^{\mathrm{m}}$ local time. Records by FM-03 magnetometer.

Рис. 7. Пример изменения геомагнитного поля $(\Delta \mathrm{T})$ 9.11.2011 года перед землетрясением в 21 час 40 мин (магнитометр FM-03).

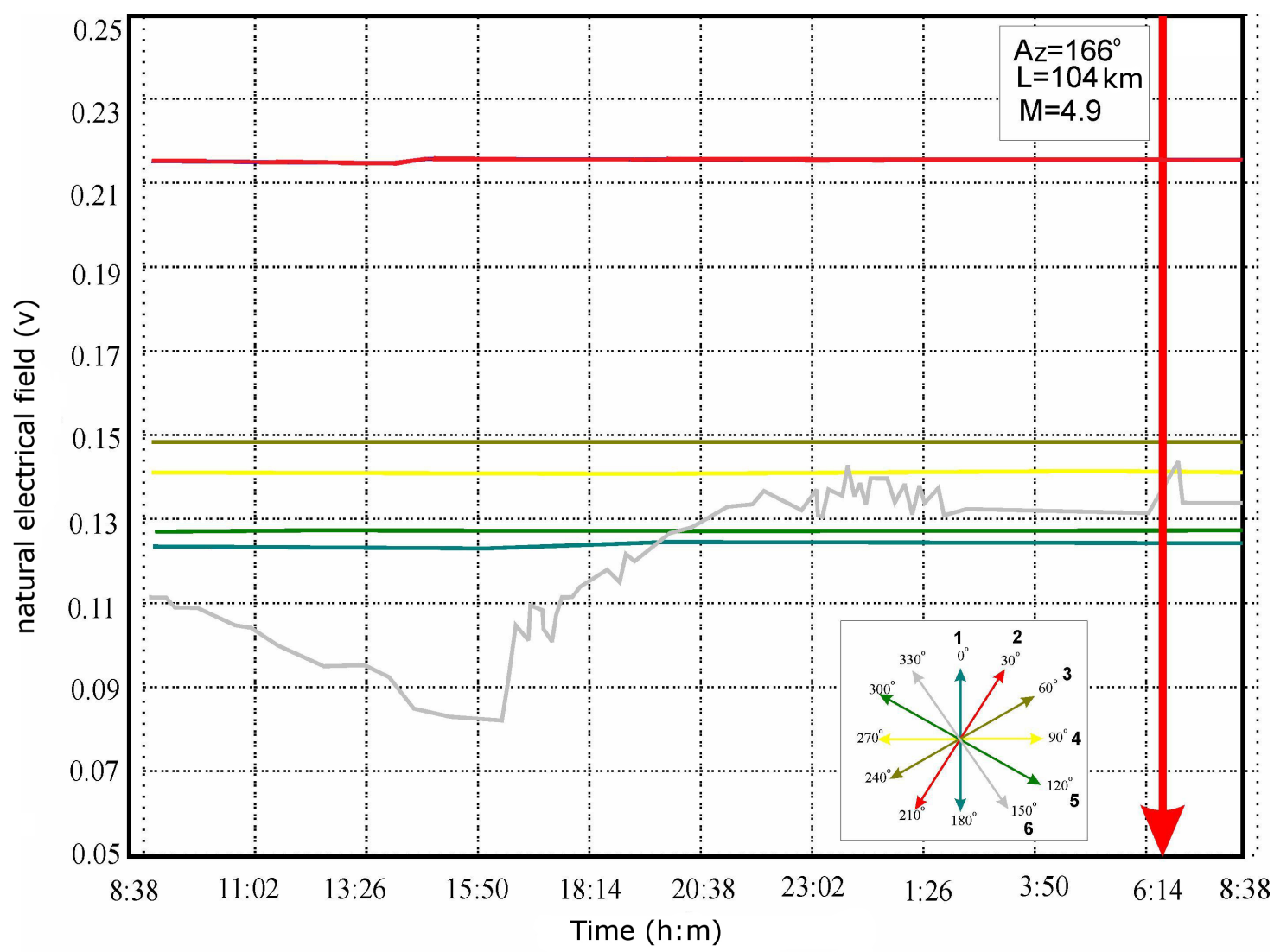

Fig. 8. Variations in the natural electric field before 13 October 2011 earthquake. The channel was oriented at azimuth $150^{\circ}$. The first sharp deviations from the background values were recorded 22 hours before the earthquake.

Рис. 8. Пример изменения естественного электрического поля при близком землетрясении 13 октября 2011 года на канале, ориентированном по азимуту $150^{\circ}$. Резкие отклонения от фонового состояния начинаются за 22 часа до землетрясения. 


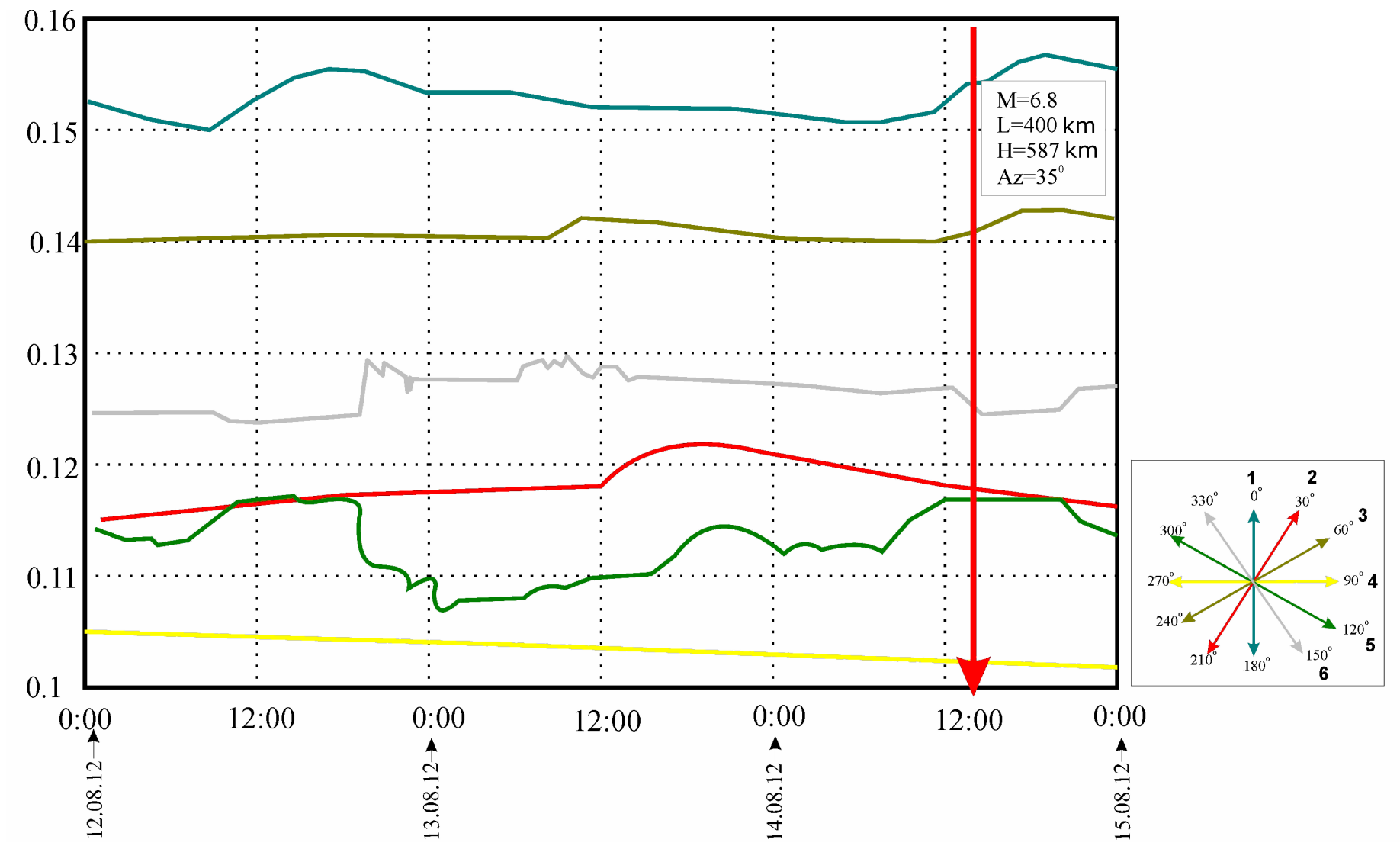

Fig. 9. Perturbations of the natural electric field before 14 August 2012 earthquake at $14^{\mathrm{h}} 00^{\mathrm{m}}$ local time. $\mathrm{H}-\mathrm{earthquake}$ hypocenter depth.

Рис. 9. Пример возмущения естественного электрического поля перед сильным землетрясением 14 августа 2012 г. в 14 часов 00 мин. Н - глубина гипоцентра землетрясений.

the adjacent channels. Monitoring was conducted in favourable conditions (dry weather, sunny days, and normal atmospheric pressure). At the current stage of the study, we fail to find a satisfactory explanation of the fact that the amplitude perturbations were recorded only in channel 6 and absent in other channels. In our future monitoring cycles, we plan to use two sets of recording equipment with dipoles arranged in parallel with each other. Should the majority of records be confirmed in the proposed recording scheme, we will define the conditions and find a physical explanation.

The above-described main results of the long-term geophysical monitoring by the multi-channel station are based on the records of more than 70 episodes when perturbations of the geophysical fields correlated with the final stages of preparation of the seismic events registered by the Sakhalin Seismological Survey. Such results may have given grounds for establishing regularities, but Figures 9 and 10 need to be taken into account as they show responses of the geophysical fields to the strong (yet quite distant) earthquake that occurred on 14 August 2012 in the Sea of Okhotsk at the eastern coast of the Sakhalin Island at a distance of
$400 \mathrm{~km}$ from the monitoring site. The true azimuth from the monitoring site to the epicentre was $35^{\circ}$.

Figure 9 shows that the first deviations from the background values were recorded at $03^{\mathrm{h}} 00^{\mathrm{m}}$ local time on 12 August 2012; the readings were recorded in channel 2 oriented at the true azimuth of $30^{\circ}$. Field perturbations began with a fairly smooth increase of the signal's amplitude by 7-8 $\mathrm{mV}$. The records at $19 \mathrm{~h} 20^{\mathrm{m}}$ local time show that the signal's sign was changed abruptly and reduced by $7 \mathrm{mV}$ and, later on, by $10 \mathrm{mV}$. Simultaneously with the change of the signal's sign in channel 2, sharp perturbations were recorded in channel 6 oriented at azimuth $330^{\circ}$, but with the positive sign and an amplitude of $6 \mathrm{mV}$. In channels 2 and 6, perturbations continued until the seismic event, but more abrupt changes in voltage were recorded on channel 2 oriented towards the earthquake epicentre. In other channels, except channel 4, weak perturbations were recorded, though they were considerably less pronounced than signals in channels 2 and 6.

It should be noted that three hours before the seismic event, a short-term stabilization of the field, 


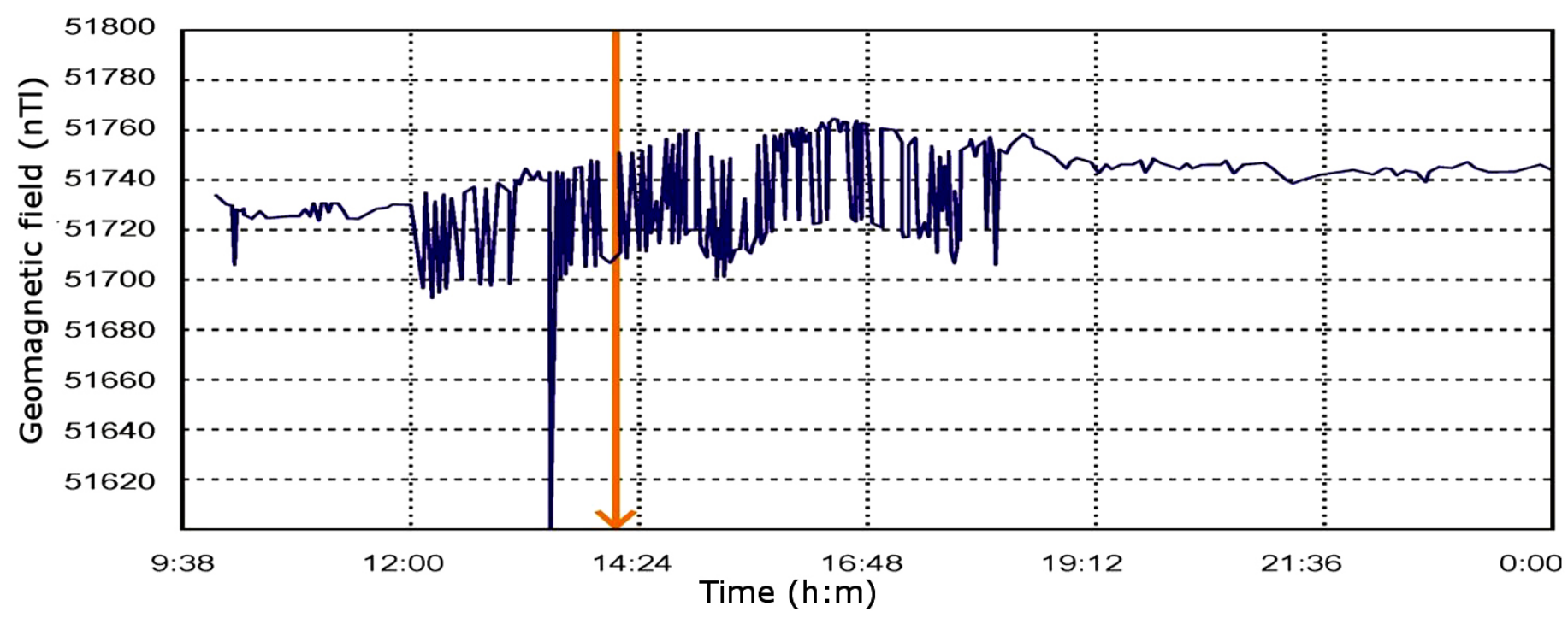

Fig. 10. Response of the geomagnetic field, $\Delta \mathrm{T}$ to 14 August 2012 earthquake.

Рис. 10. Пример реакции геомагнитного поля $(\Delta \mathrm{T})$ на землетрясение 14 августа 2012 г.

which indicated that an earthquake would soon occur, was registered in almost all the recorded episodes, including the episode recorded in channel 6 from $01^{\mathrm{h}} 40^{\mathrm{m}}$ to $05^{\mathrm{h}} 50^{\mathrm{m}}$ local time (see Fig. 8).

It should be also noted that perturbations of the natural electric field, which occurred prior to $14 \mathrm{Au}$ gust 2012 earthquake, were very different from the previously recorded disturbances. In our experimental study, however, this is the first episode with registration of an earthquake with $M>6$ which epicentre was located at a depth below $500 \mathrm{~km}$. This earthquake may need to be classified in a special category of seismic events, if we consider how it was reflected in the geophysical fields, and this special category deserves further studies.

A response of the geomagnetic field to 14 August 2012 earthquake was recorded by a proton procession magnetometer (MMP 203 with one-minute resolution) (Fig. 10). In this case, variations in the geomagnetic field occurred significantly later, only two hours before the earthquake, but with a higher amplitude and staggered repetition rate. A record taken 40 minutes before the seismic event shows that the signal amplitude exceeded $100 \mathrm{nT}$, and a 20-minute stabilization period was recorded right before the seismic event.

Among variations in the geomagnetic field (unlike those in the natural electric field), natural daily variations in the geomagnetic field are clearly detectable and rejected from the pool of precursors, while it is possible to detect signals that occur before an earthquake.

A response of the thermal field to the coming seismic event is not always clearly detectable if sensors are located at shallow depths $(3.2 \mathrm{~m})$. The most vivid example of temperature variations in relation to 01 October 2011 earthquake is shown in Figure 11.

\section{ConCluSions}

The obtained materials give grounds for the following conclusions:

(1) The hydrocarbon deposit located in the zone impacted by the active tectonic fault is highly sensitive to changes in the natural geophysical fields, and its data may be used to reveal and record such changes that characterize the final phase of preparation of earthquakes;

(2) Monitoring of the natural electric field can provide the most informative data for forecasting of seismic events. Based on electrical survey data, timing of a coming seismic event can be quite reliably determined a few hours prior to its occurrence. Moreover, it is possible to specify the azimuthal orientation from the monitoring site to the epicentre;

(3) Temperature logging and magnetic measurements can provide data allowing a more precise determination of timing of the coming seismic event. However, under the current registration system, such data do not allow to specify the direction to the epicentre.

Conclusion 2 suggests that in case of synchronous monitoring by three polygons with spacing to remote no less than $250-300 \mathrm{~km}$, it can be possible to determine coordinates of the future earthquake epicentre by the crosscut location method that is widely applied in geodesy. 


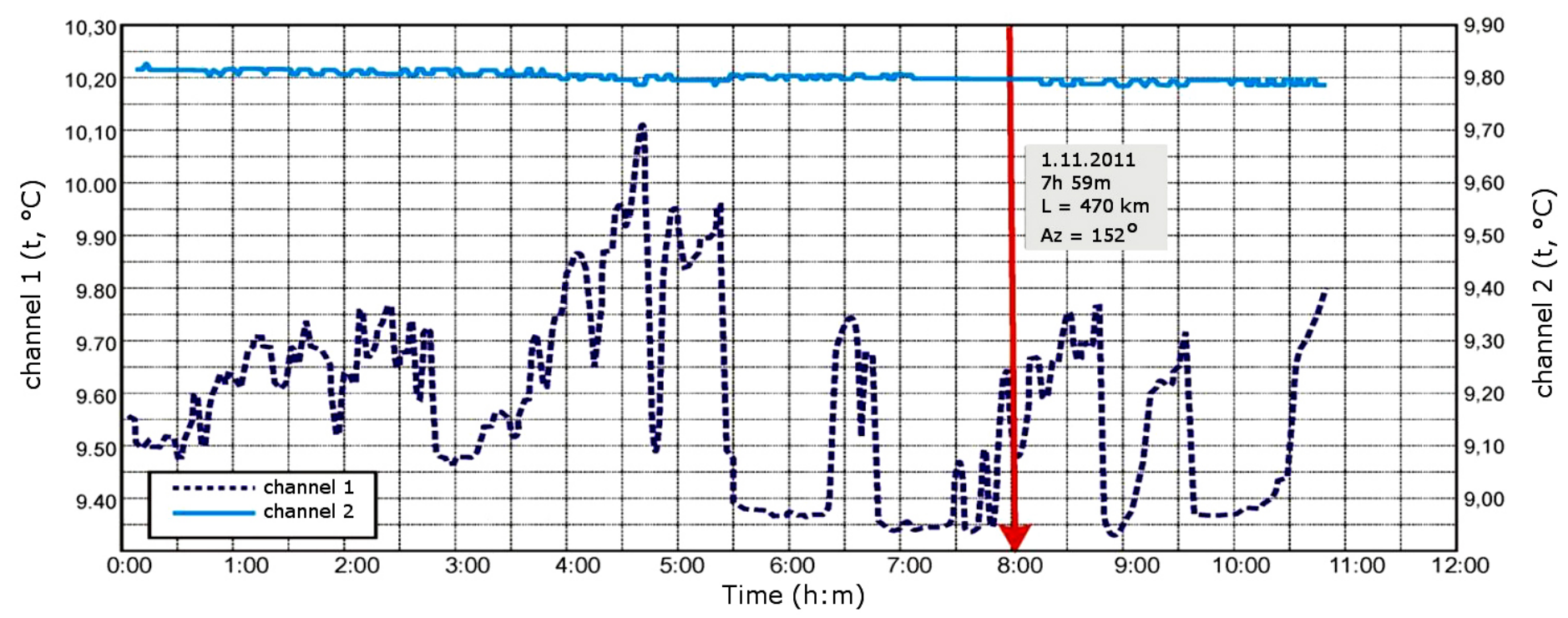

Fig. 11. Temperature variations with time before 01 October 2011 earthquake. Locations of sensors at depth: channel 1 $3.2 \mathrm{~m}$; channel $2-0.6 \mathrm{~m}$.

Рис. 11. Пример временных изменений температур перед землетрясением 1.11.2011 г. Положение датчиков по глубине: канал 1 - 3.2 м; канал $2-0.6$ м.

It is worth noting that there may be a potential of using the multichannel station for monitoring the electric field and determining the time of a coming seismic event not only above hydrocarbon deposits. A ninechannel station was successfully used in Wakayama in August 1993 [Johnston, 1997, p. 454-455] when variations in the electric field were recorded before earthquakes ( $\mathrm{M}=3.1$ and 4.2$)$.

In conclusion, it should be noted that in our experimental study, we did not aim at finding a solution for the problem of forecasting strong and hazardous earthquakes. This class of seismic events can be distinguished later, after consolidating statistically reliable data into an ample database and determining criteria for classification of events by parameters of temporal variations in geophysical fields.
At the current stage of our studies, we do not consider any theoretical aspects of geophysical field anomalies (which are convincingly described in [Dobrovolsky, 2009] and provide an explanation of processes observed in our experimental study).

Our main target herein is to publish the obtained results that seem promising for further development of our studies with a potential for elaboration of an efficient earthquake prediction technique showing timing and locations of coming seismic events.

This study was supported by RFBR Joint Grant, FEB RAS No. 11-05-98589-r_vostok_a - Development of the technique for short-term forecasting of seismic events on the basis of changes in geophysical fields above gascontaining geodynamic systems.

\section{REFERENCES}

Bulanzhe B.A., 1986. The impact of changes in hydrogeological factors in time on gravity. In: Repeated gravimetry surveys. IEP, Moscow, p. 4-23 (in Russian) [Буланже Б.А. Влияние изменения во времени гидрогеологических факторов на силу тяжести // Повторные гравиметрические наблюдения. М.: ИФЗ, 1986. С. 4-23].

Chekalyuk E.B., Fedortsov I.M., Osadchy V.G., 1974. Field Geothermal Survey. Naukova Dumka, Kiev, 104 p. (in Russian) [Чекалюк Э.Б., Федорцов И.М., Осадчий В.Г. Полевая геотермическая съемка. Киев: Наукова думка, 1974. 104 c.].

Dobrovolsky I.P., 2009. The Mathematical Theory of Tectonic Earthquake Preparation and Forecasting. Fizmatlit, Moscow, 236 p. (in Russian) [Добровольский И.П. Математическая теория подготовки и прогноза тектонического землетрясения. М.: Физматлит, 2009. 236 с.].

Johnston M.J.S., 1997. Review of electric and magnetic fields accompanying seismic and volcanic activity. Surveys in Geophysics 18 (5), 441-476. http://dx.doi.org/10.1023/A:1006500408086. 
Osadchy V.G., Lurie I.F., Erofeev V.F., 1976. Geothermal Criteria of Subsoil Oil and Gas-Bearing Capacities. Naukova Dumka, Kiev, 142 p. (in Russian) [Осадчий В.Г., Лурье А.И., Ерофеев В.Ф. Геотермические критерии нефтегазоносности недр. Киев: Наукова думка, 1976. 142 с.].

Osika D.G., 1981. Fluid Regime of Seismically Active Regions. Nauka, Moscow, 203 p. (in Russian) [Осика Д.Г. Флюидный режим сейсмически активных областей. М.: Наука, 1981. 203 с.].

Parovyshny V.A., Senachin V.N., Veselov O.V., Kochergin E.V., 2009. Variations of geophysical fields above fluid-saturated geodynamic systems in relation to seismicity forecasting issues. Vestnik DVO RAN (4), 50-58 (in Russian) [Паровышный В.А., Сеначин В.Н., Веселов О.В., Кочергин Е.В. Вариации геофизических полей над флюидонасыщенными геодинамическими системами в связи с проблемой прогноза сейсмических событий // Вестник ДВО РАН. 2009. № 4. С. 50-58].

Parovyshny V.A., Veselov O.V., Senachin V.N., Kirienko V.S., 2008. Time variations in the geophysical fields above a gas field on Sakhalin Island. Russian Journal of Pacific Geology 2 (4), 283-293. http://dx.doi.org/10.1134/S1819714 008040015.

Volgina A.I., 1988. On the impact of fluid migration on gravity changes. In: Repeated gravimetry surveys. IEP, Moscow, p. 181-185 (in Russian) [Волгина А.И. О влиянии миграции флюидов на изменение силы тяжести // Повторные гравиметрические наблюдения. М.: ИФЗ, 1988. С. 181-185].

Volgina A.I., 1990. Results of studying changes in gravity field in time. Geologiya Nefti i Gaza (3), 36-37 (in Russian) [Волгина А.И. Результаты изучения временных изменений гравитационного поля // Геология нефти и га3a. 1990. № 3. С. 36-37].
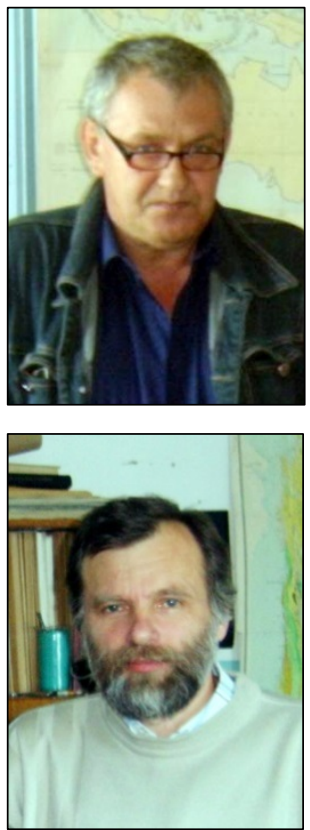

Parovyshny, Valery A., Candidate of Geology and Mineralogy, Senior Researcher Institute of Marine Geology and Geophysics, Far East Branch of RAS 1B Nauki street, Yuzhno-Sakhalinsk 693022, Russia e-mail: pva@imgg.ru

Паровышный Валерий Андреевич, канд. геол.-мин. наук, с.н.с. Институт морской геологии и геофизики ДВО РАН 693022, Южно-Сахалинск, ул. Науки, 1 Б, Россия 凶 e-mail: pva@imgg.ru

Senachin, Vladimir N., Candidate of Geology and Mineralogy, Lead Researcher Institute of Marine Geology and Geophysics, Far East Branch of RAS 1B Nauki street, Yuzhno-Sakhalinsk 693022, Russia

Сеначин Владимир Николаевич, канд. геол.-мин. наук, в.н.с. Институт морской геологии и геофизики ДВО РАН 693022, Южно-Сахалинск, ул. Науки, 1 Б, Россия 


\section{V.A. Parovyshny et al.: Temporal variations in geophysical fields...}

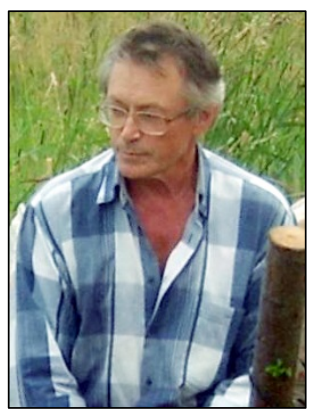

Veselov, Oleg V., Candidate of Geology and Mineralogy, Lead Researcher Institute of Marine Geology and Geophysics, Far East Branch of RAS

1B Nauki street, Yuzhno-Sakhalinsk 693022, Russia

Веселов Олег Васильевич, канд. геол.-мин. наук, в.н.с.

Институт морской геологии и геофизики ДВО РАН

693022, Южно-Сахалинск, ул. Науки, 1 Б, Россия

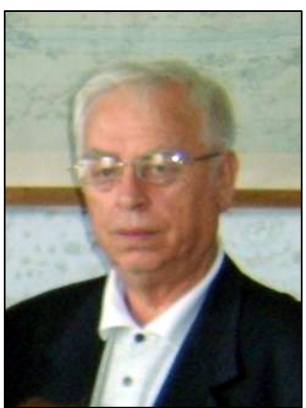

Kochergin, Evgeny V., Candidate of Geology and Mineralogy, Senior Researcher Institute of Marine Geology and Geophysics, Far East Branch of RAS

1B Nauki street, Yuzhno-Sakhalinsk 693022, Russia

Кочергин Евгений Васильевич, канд. геол.-мин. наук, с.н.с.

Институт морской геологии и геофизики ДВО РАН

693022, Южно-Сахалинск, ул. Науки, 1 Б, Россия 